International Journal of Social Sciences and Humanities
Available online at http://sciencescholar.us/journal/index.php/ijssh
Vol. 2 No. 2, April 2018, pages: $171 \sim 181$
e-ISSN: 2550-7001, p-ISSN: 2550-701X
http://dx.doi.org/10.29332/ijssh.v2n1.140

\title{
Education and Job Training on Employee Performance
}

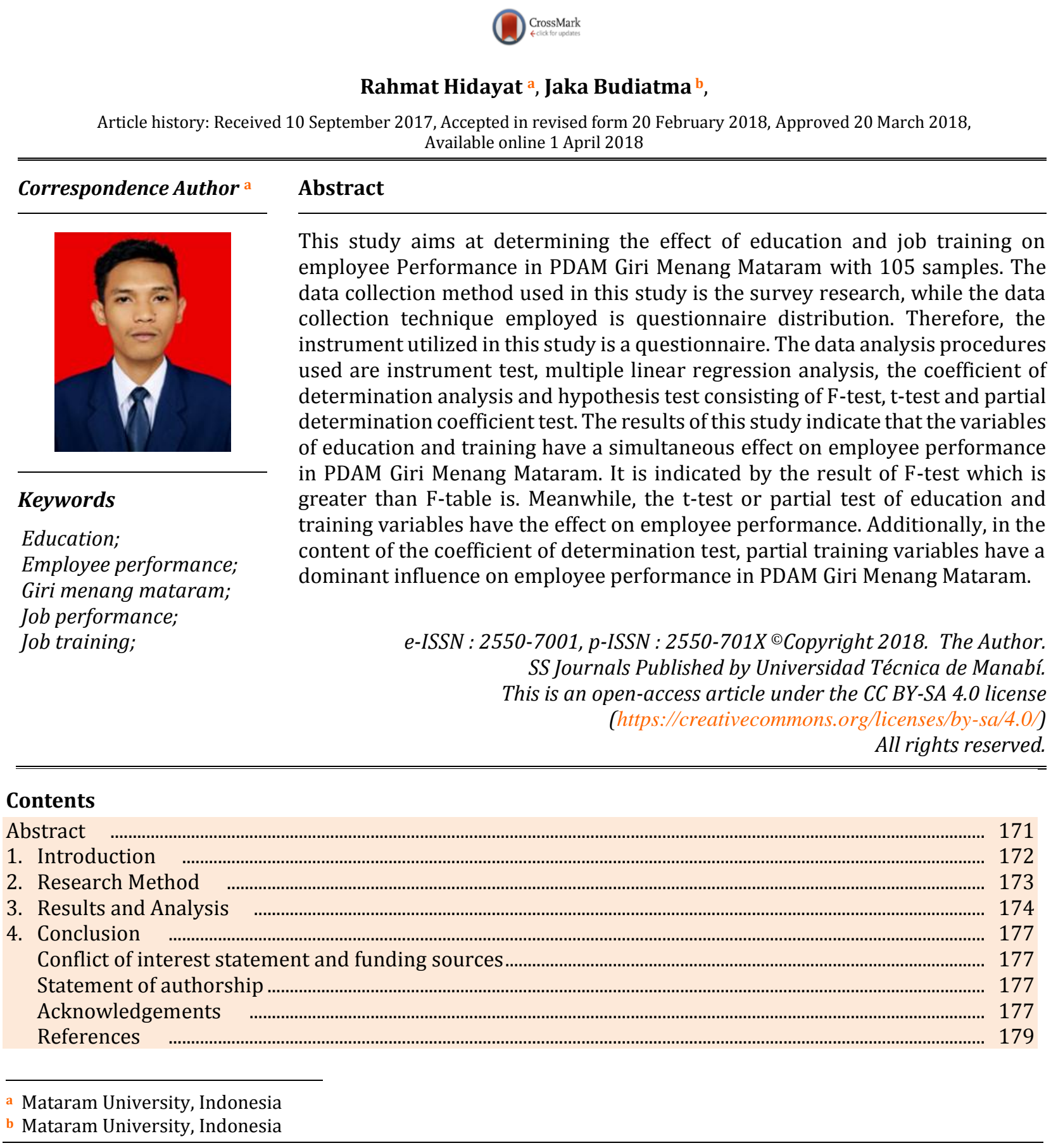




\section{Introduction}

The role of human resource management is crucial for the realization of an organization. However, to lead a human being is quite difficult. Besides being capable, skillful and competent, employees are also expected to have high motivation and commitment to work effectively and efficiently. Abilities and skills will be less meaningful if it is not followed by work morale and employee discipline in realizing goals. To realize these all considerations, it demands the empowerment of human resources as planners and implementers in the organization, one of which is by providing education and training of employees.

The education and training program for an employee is expected to provide motivation for employees in improving their performance skills and subsequently able to improve employee achievement. Education and training are one of the traditional functions of human resource management that will be able to improve employee performance or achievement (Sutrisno, 2011: 151).

Education and training are key in management that plays an important and strategic role in improving job performance or achievement (Sutrisno, 2011: 151). Development of human resources through education and training is an operational function in human resource management. Its use in an institution or organization is usually incorporated into a training (education and training). Implementation of education and training is directed to the improvement of skills, knowledge and attitude change or employee behavior, the learning process expected in education and training is expected to change the employees from the less know to know more and less skilled to be skilled and negative attitude and behavior to be positive and etc. Education and training have different meanings.

According to Notoatmojo (1998: 21), education, in general, is concerned with preparing candidates for employment by an organization or institution while training related to the improvement of skills or skills of employees who have occupied an office. Flippo (1979: 53) states that education is linked to the improvement of general knowledge and understanding of the whole environment around us, while training is an activity to improve the knowledge and skills of employees in common work every day. A similar point is expressed by Ranupandojo (1986: 6) that education is a desire to improve one's general knowledge including enhancement of theory and skill mastery, formulating various issues concerning activities in the achievement of goals.

Based on the above definition, the education and training are not the same, but both of them have a close relationship. Education is meant to increase knowledge and be more theoretical while training is the application of knowledge and skills improvement, so it is more practical. Although they have different meanings the purpose of education and training is the same that is to improve job performance or achievement for employees in an organization or company.

Job performance is a work achieved by a person in performing tasks assigned to him based on his skills, experience and sincerity and time (Hasibuan 2011: 94). According to Sirait (2006: 128) Job performance is the process of evaluation or performance of employees conducted by the organization. While Mangkunegara (2009: 67), explained that the achievement of work is the work of quality and quantity achieved by an employee in performing their duties in accordance with the responsibilities given to him.

A number of factors possibly affect job performance or achievement. The factors that influence the job performance or achievement are leadership, work environment, work discipline, work motivation, education and job training (Sutrisno, 2011: 151). The above statement is reinforced by Moses's (2012) research to get the result that education and job training have an effect on job performance.

PDAM Giri Menang Mataram which is used as an object in this research is a company engaged in the field of mineral water supply or clean water for people throughout the region of West Lombok and Mataram City. PDAM Giri Menang Mataram is located at Jl. Pendidikan No.39 Mataram. PDAM Giri Menang Mataram formerly named PDAM West Lombok regency was established since 1973. The number of employees in PDAM Giri Menang Mataram in 2014 is 263 employees with 239 permanent employees and 37 non-permanent employees. Employee placement on PDAM Giri Menang Mataram as follows: 3 Directors 3, 143 Finance and General employees, 105 Engineers, 3 employees of R \& D, and 9 SPI. However, this study only focuses on the technical part because it is in this section of education and training programs should be more applied to each employee, especially competence that are skill compared with other parts. 
In carrying out its operations the company uses various ways to achieve organizational goals one of them is by providing education and job training programs to the workers who also have an impact on improving employee performance itself.

The conceptual framework of this study can be pictured as follows:

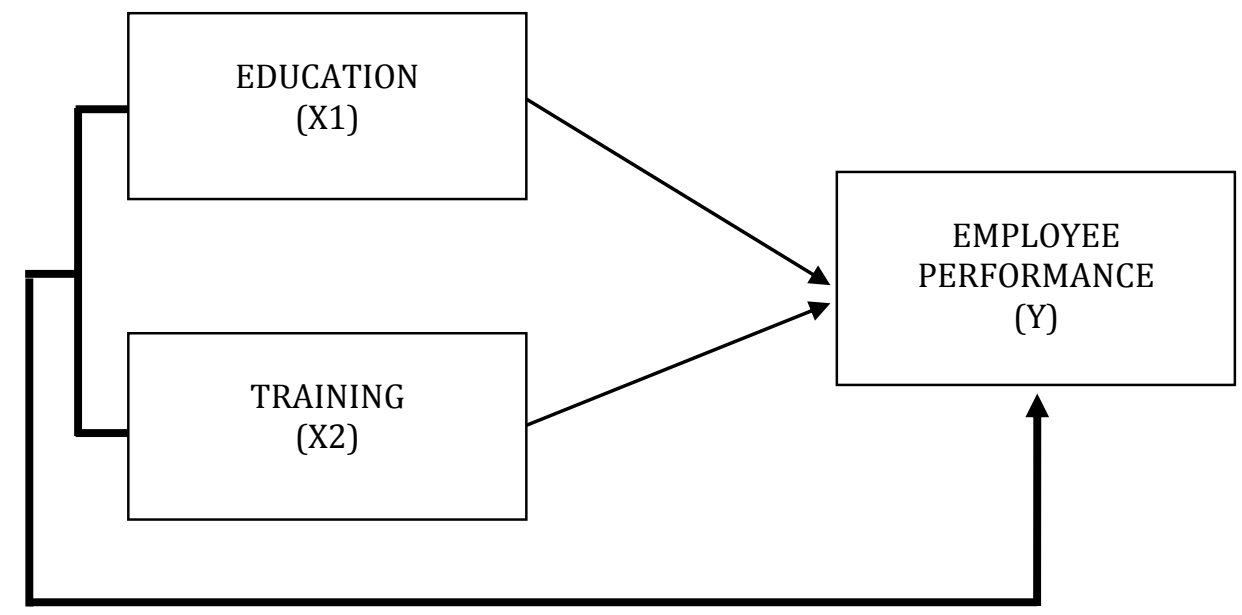

Picture 1. Conceptual Framework of the Study

Notes:

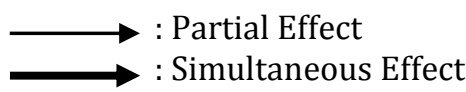

\section{Research Method}

The type of research used in this study is associative research. This associative research is a study that aims at examining the relationship between two or more variables. Through this research, it can be built a theory that can serve to explain, predict and control a symptom (Sugiyono, 2006: 11). This research was conducted in PDAM Giri Menang Mataram located at J1. Pendidikan No. 39 Mataram.

Data collection method used in this research is survey research. In this case, the data comes from all subjects in the population, not just from the sample. (Sangdji, 2010: 31). Sugiyono (2006: 57) gives the understanding that: "Population is a generalization region consisting of objects or subjects that become quantities and certain characteristics set by researchers to be learned and then drawn conclusions. Population in this research is all employee of technique part at PDAM Giri Menang Mataram. In this study, all populations were taken as respondents who are 105 people.

The technique of data collection is questionnaire distribution. A questionnaire is a number of questions that must be answered or responded by the respondent. Respondents have the freedom to provide answers or responses according to their perceptions (Sutopo, 2006: 87). The data collection tool in this research is using a questionnaire. Questionnaires are a number of written questions used to obtain information from the respondent, in the sense of a report about his personality for the things that they know (Sutopo, 2006: 88).

The type of data used in this study is basically qualitative data which is then converted into quantitative data in the form of scores or numbers obtained from respondents' answers to the questionnaire.

The data used in this research is divided into two types namely primary and secondary data (Supranto, 2000: 11):

a) Primary Data, the data obtained directly from the respondents who become the object in this study in the form of responses of respondents about education and job training towards employee work performance.

b) Secondary Data, namely supporting data obtained from related companies, books, and other literature related to this research is about education and job training on employee performance.

Hidayat, R., \& Budiatma, J. (2018). Education and Job Training on Employee Performance. International Journal Of Social Sciences And Humanities (IJSSH), 2(1), 171-181. doi:10.29332/ijssh.v2n1.140 
To obtain data related to education and job training and job performance, its use the instrument in the form of questionnaires with measurements using a Likert scale which has five levels which are the scale of an ordinal type. By using two instruments, namely education and training, and work performance which then developed into questions or parameters to be measured.

Data quality test includes a validity and reliability test. Validity test is required because a measurement instrument is said to be valid if the instrument measures what should be measured. In this research, researchers will measure the education, training and employee performance on PDAM Giri Menang Mataram. To test the validity used Product Moment technique on SPSS 16.0 for windows program. The instrument item is said to be valid if it is greater than 0.3 or biased also by comparing it with $r$ table. If $r$-test $>r$ table then it can be said valid.

Reliability test is needed because a questionnaire is said to be reliable if one's answer to the question is consistent. To know the reliability of the instrument in this study then the measurement is done by using Alpha Cronbach. This test uses SPSS 16.0 for windows with Cronbach Alpha value must be above 0.6 barn data is said to be reliable.

The classical assumption test is a statistical requirement that must be met in multiple linear regression analysis. There are at least four classical assumption tests, namely normality test, multicollinearity test, autocorrelation test, and heteroscedasticity test. A classical assumption test is necessary to produce an unbiased linear estimator with a minimum linear (Best Linear Unbiased Estimator = BLUE), which means that the regression model is problematic.

Multiple linear regression analysis was used to test the hypothesis in this study. Systematically this analysis is expressed in terms of statistical equations (Wirawan, 2002: 293)

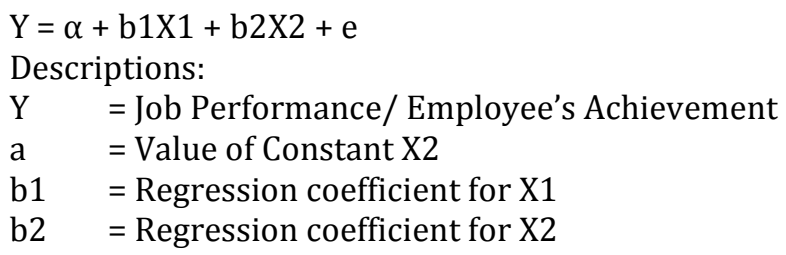

$\begin{array}{ll}\mathrm{X} 1 & =\text { Education } \\ \mathrm{X} 2 & =\text { Training } \\ \mathrm{e} & =\text { Bake Error }\end{array}$

\section{Results and Analysis}

\section{Discussion}

The result of the validity test conducted in this research shows the same result that is a valid calculation. More details of the questionnaire test in this study for the variables of Education can be seen in table 1 below.

Table 1

Validity test of education

\begin{tabular}{ccccc}
\hline No. & The indicator of Education & Correlation & Significance & Criterion \\
\hline 1. & $\mathrm{X} 1.1$ & 0,516 & 0,000 & Valid \\
2. & $\mathrm{X} 1.2$ & 0,457 & 0,000 & Valid \\
3. & $\mathrm{X} 1.3$ & 0,660 & 0,000 & Valid \\
\hline
\end{tabular}

Based on Table 1, it shows that the correlation significance for each of the educational instruments is smaller than 0.05 . It can be concluded that each educational instrument is valid. Therefore, all instruments can be used in the processing of multiple linear regression data.

The result of validity test conducted in this research show the same result, that is the result of the valid calculation. The following test results validity questionnaire research for training variables as shown in table 2 Below. 
Tabel 2

Validity test of training

\begin{tabular}{ccccc}
\hline No. & The Indicator of Training & Correlation & Significance & Criterion \\
\hline 1. & X2.1 & 0,591 & 0,000 & valid \\
2. & X2.2 & 0,425 & 0,000 & valid \\
3. & X2.3 & 0,481 & 0,000 & valid \\
4. & X2.4 & 0,141 & 0,036 & valid \\
5. & X2.5 & 0,287 & 0,000 & valid \\
6. & X2.7 & 0,320 & 0,000 & valid \\
7. & X2.8 & 0,336 & 0,000 & Valid \\
8 & $\mathrm{X} 2.9$ & 0,317 & 0,000 & Valid \\
9 & $\mathrm{X} 2.10$ & 0,397 & 0,000 & Valid \\
10 & & 0,683 & 0,000 & Valid \\
\hline
\end{tabular}

Based on Table 2, it appears that the correlation significance value for each Training instrument is smaller than 0.05 . Therefore, it can be concluded that each Training instrument is valid.

The result of the validity test of research questionnaire for employee achievement variable is shown in table 3, below. Based on table 3, It appears that the value of correlation significance for each instrument of Employee Performance or achievement is also smaller than 0.05 , so it can be concluded that each instrument of Job Performance or achievement is valid.

Tabel 3

Validity test of employee's achievement

\begin{tabular}{ccccc}
\hline No. & $\begin{array}{c}\text { The Indicator of Employee's } \\
\text { Achievement }\end{array}$ & Correlation & Significance & Criterion \\
\hline 1. & Y1.1 & 0.616 & 0,000 & Valid \\
2. & Y1.2 & 0.597 & 0,000 & Valid \\
3. & Y1.3 & 0.595 & 0,000 & Valid \\
4. & Y1.4 & 0.351 & 0,000 & Valid \\
5. & Y1.6 & 0.591 & 0,000 & Valid \\
6. & Y1.7 & 0.605 & 0,000 & Valid \\
7. & Y1.8 & 0.516 & 0,000 & Valid \\
8. & 0,740 & 0,000 & Valid \\
\hline
\end{tabular}

The results of the reliability test of the research questionnaire for the variable of education is shown in Table 4 below.

Tabel 4

Reliability test of education

\begin{tabular}{cccc}
\hline No. & The indicator of Education & $\begin{array}{c}\text { Cronbach' } \\
\text { S Alpha }\end{array}$ & Criterion \\
\hline 1. & Education & 0,622 & Reliable \\
2. & Training & 0,642 & Reliable \\
3. & Achievement & 0,736 & Reliable \\
\hline
\end{tabular}

Based on table 4, it appears that the value of Cronbach's alpha for each instrument of Education, Training, and Job Performance is greater than 0.60 . Therefore, it can be concluded that each instrument of this research is reliable.

Hidayat, R., \& Budiatma, J. (2018). Education and Job Training on Employee Performance. International Journal Of Social Sciences And Humanities (IJSSH), 2(1), 171-181. doi:10.29332/ijssh.v2n1.140 
To see how the regression function that can be formulated from the calculation results with SPSS 13.0 this article presents the table 5 . below.

Table 5

Individual parameter significance

\begin{tabular}{llcc}
\hline \multirow{2}{*}{ Model } & \multicolumn{2}{c}{ Unstandardized Coefficients } \\
& B & Std. Error \\
\hline 1. & (Constant) & 1,422 & 0,531 \\
Education & 0,209 & 0,110 \\
Training & 0,530 & 0,099 \\
\hline
\end{tabular}

a Dependent Variable: Employee Performance/Achievement

Based on the table 5 above it can be formulated the function of linear regression as follows:

$$
Y=1,422+0,654 X_{1}+0,530 X_{2}
$$

Notes:

$\begin{array}{llll}\text { Constants } & =1,422 & \mathrm{Y} & =\text { Employee's achievement } \\ \mathrm{b}_{1} & =0,209 & \mathrm{x}_{1} & =\text { Education } \\ \mathrm{b}_{2} & =0,530 & \mathrm{x}_{2} & =\text { Training }\end{array}$

The result of the simultaneous determination test (R2) can be seen in table 6, Below:

Table 6

Simultaneous determination test results model summary

\begin{tabular}{|c|c|c|c|c|}
\hline Model & $\mathrm{R}$ & R Square & Adjusted R Square & Std. The error of the Estimate \\
\hline 1 & $589^{a}$ & 346 & 334 & 28899 \\
\hline
\end{tabular}

Predictors: (Constant), X2, X1

Dependent Variable: Employee Performance/Achievement

Based on table 6, it can be described that the value of R Square (R2) is 0.346 , this means that $34.6 \%$ variation Employee Work Performance can be explained by the variation of the two independent variables of Education and Training. While the rest $(100 \% \neg 34.6 \%=66.4 \%)$ is explained by other causes from outside the model not included in this research model.

To see how the partial influence of Education and Training on Employee Work Achievement in PDAM Giri Menang Mataram, this study used a t-test. From the information provided in table 7., It can be seen that the value of the $t$-test positive for education variables is 4.484 and $t$-test positive for Training variables is 4.508 . To find the answers to the hypothesis that there is a need to be compared between $t$-test and $t$ table.

Table 7

The result of a t-test of the independent variable to the dependent variable

\begin{tabular}{|c|c|c|c|c|c|}
\hline \multirow{2}{*}{ Model } & \multicolumn{2}{|c|}{ Unstandardized Coefficients } & \multirow{2}{*}{$\begin{array}{c}\text { Standardized Coefficients } \\
\text { Beta }\end{array}$} & \multirow[b]{2}{*}{$t$} & \multirow{2}{*}{ Sig. } \\
\hline & B & Std. Error & & & \\
\hline 1(Constant) & 649 & ,531 & \multirow{3}{*}{$\begin{array}{l}, 411 \\
413\end{array}$} & 1,223 & 225 \\
\hline $\mathrm{X} 1$ & ,494 & 110 & & 4,484 & '000 \\
\hline $\mathrm{X} 2$ & 445 & '099 & & 4,508 & '000 \\
\hline
\end{tabular}

Dependent variable: employee performance/achievement 
Using 95\% confidence level where $\mathrm{a}=5 \%$, df (degree of freedom) $\mathrm{n}-\mathrm{k}-1=105-2-1=102$, so that the result for $\mathrm{t}$ table is equal to 1,983. Therefore, t-test of Education $>\mathrm{t}$-table $(4,484>1,983)$ and $\mathrm{t}$-test of training $>\mathrm{t}$-table $(4,508>1,983)$. Hence, it can be concluded that there is partially significant influence of Education and Training on Employee Work Achievement at PDAM Giri Menang Mataram.

To see how the significant effect simultaneously of Education and Training on Employee Work Achievement in PDAM Giri Menang Mataram, it is used F-test. The following table 6. presents the results of F-test with SPSS 13.0.

Table 8

The result of F-test of independent variables on dependent variables

\begin{tabular}{|ll|r|r|r|r|r|}
\hline & Model & \multicolumn{1}{c|}{$\begin{array}{c}\text { Sum of } \\
\text { Squares }\end{array}$} & Df & Mean Square & F & \multicolumn{1}{c|}{ Sig, } \\
\hline 1 & Regression & 4,514 & 2 & 2,257 & 27,027 & $000^{\mathrm{a}}$ \\
Residual & 8,518 & 102 &, 084 & & \\
Total & 13,033 & 104 & & & \\
\hline
\end{tabular}

Dependent variable: employee performance/ achievement

Based on table 8. above, the value of F-test is equal to 24,707 . Then, using a $95 \%$ confidence level, a $=5 \%$, DF1 (number of variable-1) $=3-1=2$, and DF2 (nk-1) $=105-2-1=102$, the result for the F table is to 3.085. Therefore, F-test $>$ F-table $(24.707>3.085)$. Hence, it can be concluded that there is significant influence simultaneously of Education and Training to Employees' Achievement in PDAM Giri Menang Mataram.

Table 9

Partial correlation test results on SPSS 13.0

\begin{tabular}{lccc}
\hline \multicolumn{1}{c}{ Model } & & Correlations & \\
& Zero-order & Partial & Part \\
\hline Education & 0,416 & 0,416 & 0,271 \\
Training & 0,523 & 0,458 & 0,416 \\
\hline
\end{tabular}

Dependent Variable: Employee's Achievement

Based on Table 9. above, the partial correlation coefficient of Education is 0.4162 and Training of 0.4582 . This shows that the training has a more dominant influence on Employee Achievement PDAM Giri Menang Mataram.

Based on the discussion of data that has been done, it can be interpreted that: (1) based on Simultaneous Determination Test (R2), the R Square (R2) obtained is 0.346 meaning that $34.6 \%$ variation Employee Work Performance can be explained by the variation of both independent variables namely Education and Training. While the rest $(100 \%-34.6 \%=66.4 \%)$ is explained by other causes from outside the model that is not included in the model of this study, (2) through the value of $t$-test obtained, it can be pictured that $t$-test of Education $>t$ table $(4,484>1,983)$ and $t$-test of training $>T$ table $(4,508>1,983)$. Hence, it can be concluded that there is the partially significant influence of Education and Training on Employee Work Achievement at PDAM Giri Menang Mataram, (3) through F test, it is obtained that the value of F-test> F table $(24,707>3,085)$. Therefore, it can be concluded that there is a significant simultaneous effect of Education and Training on Employee Performance at PDAM Giri Menang Mataram, (4) based on the calculation of partial determination coefficient, it shows that partial correlation coefficient of Education is 0.416 and Training is 0.458 . This shows that the training has a more dominant effect on Employee Achievement in PDAM Giri Menang Mataram.

\section{Conclusion}

From the results of the research and discussion above, the conclusion of the research that can be drawn are: (1) education and training have a partially significant effect on Employee Work Achievement at PDAM Giri Menang Mataram, (2) education and training have significant influence simultaneously on Employee Work

Hidayat, R., \& Budiatma, J. (2018). Education and Job Training on Employee Performance. International Journal Of Social Sciences And Humanities (IJSSH), 2(1), 171-181. doi:10.29332/ijssh.v2n1.140 
Achievement in PDAM Giri Menang Mataram, and (3) training has a more dominant effect on Employee's Achievement in PDAM Giri Menang Mataram.

Based upon this, this study offers several suggestions: (1) Education and Training that has been implemented is already in accordance with the demands of the duties and responsibilities of employees. Nevertheless, the education and training carried out by PDAM Giri Menang Mataram management should be enhanced to sustain future individual and organizational performance and (2) for researchers interested in the same topic, the research subject also needs to be expanded by the number of respondents so that the accuracy of the model with the variation of its influence can be even higher in affecting the individual Work Performance.

Conflict of interest statement and funding sources

The authors declared that they have no competing interest. The study was financed by the authors themselves.

Statement of authorship

The authors have a responsibility for the conception and design of the study. The authors have approved the final article.

\section{Acknowledgments}

This research journal cannot be accomplished without the aid of various parties in the form of guidance, the necessary data, criticism and suggestions and the support constantly given. My unlimited thank to my parents who always support me, both morally and materially. For H. Zainal Abidin, M. Si as the main supervisor and Dra. Handri Amien Eff, M.Si. as the second supervisor, I deliver my gratitude for your guidance during the research process. I also thank the management of PDAM Giri Menang Mataram, who has been willing to provide the required data during the research. And thanks to all people who cannot be mentioned one by one, who has provided support to researchers during this research. 


\section{References}

1. Ansoff, H. I., \& McDonnell, E. J. (1990). Implanting strategic management. Prentice hall. View in (Google Scholar)

2. Arikunto, S. (1997). Prosedur Penelitian Suatu Pendekatan Praktek, Jakarta: Rineka Cipta, 2002. Prosedur Penelitian Suatu Pendekatan Praktek.

View in (Google Scholar)

3. Billaiya, R., Malaiya, S., \& Parihar, K. S. (2017). Impact of Socio Economic Trends on Students in Quality Education System. International Journal of Social Sciences and Humanities (IJSSH), 1(1), 16-20.

View in (Google Scholar)

4. Cameron, K. S., \& Whetten, D. A. (1983). Organizational effectiveness: one model or several?. In Organizational Effectiveness (pp. 1-24).

View in (Google Scholar)

5. Carrell, M. R., Kuzmits, F. E., \& Elbert, N. F. (1992). Personnel/human resource management. Macmillan Publishing Company. View in (Google Scholar)

6. Cherrington, J. O., \& Cherrington, D. J. (1995). Ethical Decision Making. MicroMash, Englewood, CO. View in (Google Scholar)

7. Creswell, J. W. (1996). Research design. Qualitative and Quantitative Approach. Thousand Oaks: SagePublications.

View in (Google Scholar)

8. Ghozali, I. (2001). Application of Multivariate Analysis with SPSS Program. Semarang. View in (Google Scholar)

9. Hamalik, O. (2004). Proses belajar mengajar. Bumi Aksara.

View in (Google Scholar)

10. Hasbullah, S. H. (2001). Muslim Refugees, the Forgotten People in Sri Lanka's Ethnic Conflict: Introduction. Research and Action Forum for Social Development.

View in (Google Scholar)

11. Huselid, M. A. (1995). The impact of human resource management practices on turnover, productivity, and corporate financial performance. Academy of management journal, 38(3), 635-672.

View in (Google Scholar)

12. Jain, P. (2017). Effect of Online Education Trend on Quality Management. International Journal of Health Sciences (IJHS), 1(1), 1-5.

View in (Google Scholar)

13. Malaiya, S., Shrivastava, A., Prasad, G., \& Jain, P. (2017). Impact of Medical Education Trend in Community Development. International Journal of Health Sciences (IJHS), 1(1), 23-27.

View in (Google Scholar)

14. Nitisemito, A. S. (1996). Manajemen Sumber Daya Manusia. Cetakan sembilan. Jakarta: Ghalia Indonesia. View in (Google Scholar)

Hidayat, R., \& Budiatma, J. (2018). Education and Job Training on Employee Performance. International Journal Of Social Sciences And Humanities (IJSSH), 2(1), 171-181. doi:10.29332/ijssh.v2n1.140 
15. Noe, R. A., Hollenbeck, J. R., Gerhart, B., \& Wright, P. M. (2006). Human resource management. China People's University Press.

View in (Google Scholar)

16. Noe, R. A., Hollenbeck, J. R., Gerhart, B., \& Wright, P. M. (2006). Human resource management. China People's University Press.

View in (Google Scholar)

17. Notoatmodjo, S. (2003). education and health Behavior. Rineka Cipta. Jakarta.

View in (Google Scholar)

18. Sedarmayanti, D. M. P. (2003). Tata Kearsipan dengan Memanfaatkan Teknologi Modern. Bandung: CV Mandar Maju.

View in (Google Scholar)

19. Siagian, S. P. (1986). Bunga rampai managemen modern. Gunung Agung/CV Haji Masagung. View in (Google Scholar)

20. Simamora, H. (1999). Akuntansi manajemen. Jakarta: Salemba Empat. View in (Google Scholar)

21. Sirait, J. T. (2006). Memahami aspek-aspek pengelolaan sumber daya manusia dalam organisasi. Jakarta: PT Grasindo.

View in (Google Scholar)

22. Sofyandi, H. (2008). Manajemen sumber daya manusia. View in (Google Scholar)

23. Sopiah, E. M. S. (2010). Metode Penelitian. View in (Google Scholar)

24. Sugiyono, M. P. P. (2007). Pendekatan Kuantitatif. Kualitatif, dan R\&D, Bandung: Alfabeta. View in (Google Scholar)

25. Supranto, J. (2000). Teknik sampling untuk survei dan eksperimen. Jakarta: Rineka Cipta. View in (Google Scholar)

26. Sutopo, E. A. (2006). U.S. Patent Application No. 29/211,225. View in (Google Scholar)

27. Sutrisno, E., \& Rachmady, R. (2011). Preliminary Observations of the Breeding Biology of the Criticallyendangered White-shouldered Ibis Pseudibis davisoni in East Kalimantan. Kukila, 14, 32-35. View in (Google Scholar)

28. Tichy, N. M. (1981). Strategic human resource management. View in (Google Scholar)

29.Zikmund, W. G., Babin, B. J., Carr, J. C., \& Griffin, M. (2013). Business research methods. Cengage Learning. View in (Google Scholar) 


\section{Biography of Authors}

\begin{tabular}{|l|l|}
\hline & $\begin{array}{l}\text { Rahmat Hidayat born in Dompu on February 3, 1994, is the first son of two children. } \\
\text { He graduated from SMPN 1 Dompu in 2008 and then continued his study at SMAN } \\
\text { 1 Dompu and graduated in 2011. Rahmat continued his Bachelor degree in Faculty } \\
\text { of Economics and Business Mataram University and earned his bachel or degree in } \\
\text { 4 years, then since 2016, he is a student of a Master of Management study program } \\
\text { at Mataram University. } \\
\text { Email: rahmat13666@gmail.com }\end{array}$ \\
\hline \hline
\end{tabular}

Hidayat, R., \& Budiatma, J. (2018). Education and Job Training on Employee Performance. International Journal Of Social Sciences And Humanities (IJSSH), 2(1), 171-181. doi:10.29332/ijssh.v2n1.140 